\title{
Physiotherapist's role in the NASF: perception of coordinators and staff
}

\author{
Atuação do fisioterapeuta no NASF: percepção \\ dos coordenadores e da equipe
}

\author{
Cássia Cristina Braghini, Fátima Ferretti, Lucimare Ferraz*
}

Universidade de Chapecó, Chapecó, SC, Brazil

\begin{abstract}
Introduction: The work process in the Nucleus of Support for Family Health (NASF) assumes the integration of its professionals with the family health staff. Objective: To present the perceptions of staff, coordinators of the Family Health Centers (CSF) of reference, and NASF about the physiotherapist's role in the centers. Methods: This is a qualitative research guided by the case study method. The studied population was composed of the four coordinators of the CSF, the general coordinator of the centers, and eight members of NASF staff. Data collection consisted of semi-structured interviews with coordinators and focal group for the staff members. Data was analyzed using thematic content analysis. Results: The physiotherapist's role at NASF consists of actions about health education and disease prevention, organization and management of the flow of users with rehabilitation demand, prevention and treatment of occupational diseases and the development of complementary and integrative practices. The existence of obstacles in the work process of physiotherapists at NASF as disjointed planning of the Family Health Strategy (FHS) and the prioritization of health rehabilitation activities was also highlighted. Conclusion: It is evident that the physiotherapist at NASF has an important role with the health teams, regarding the attention to demands of the municipality; however, the need to consolidate the matrix support and the collective action planning became evident.
\end{abstract}

Keywords: Family Health. Health Manpower. Physical Therapy Specialty.

*CCB: MS, e-mail: cafisio@unochapeco.edu.br FF: PhD, e-mail: ferrettifisio@yahoo.com.br

LF: PhD, e-mail: lferraz@unochapeco.edu.br 
Resumo

Introdução: O processo de trabalho nos Núcleos de Apoio à Saúde da Família (NASF) pressupõe a integração de seus profissionais com a equipe de saúde da família. Objetivo: apresentar as percepções da equipe, coordenadores dos Centros de Saúde da Família (CSF) de referência e NASF sobre a atuação do fisioterapeuta nos núcleos. Métodos: Pesquisa qualitativa orientada pelo método do estudo de caso. A população do estudo foi composta pelos quatro coordenadores dos CSF, o coordenador geral dos núcleos e oito integrantes da equipe NASF. A coleta de dados consistiu em entrevista semiestruturada no caso dos coordenadores e grupo focal com os profissionais da equipe. Os dados foram analisados por meio da análise de conteúdo temática. Resultados: A atuação do fisioterapeuta no NASF consiste em ações de educação em saúde e prevenção de enfermidades, organização do fluxo e manejo dos usuários com demanda por reabilitação, prevenção e tratamento de doenças ocupacionais e desenvolvimento de práticas integrativas e complementares. Também foi destacada a existência de entraves no processo de trabalho dos fisioterapeutas no NASF como o planejamento desarticulado da Estratégia Saúde da Família (ESF) e a priorização da atuação em reabilitação da saúde. Conclusão: Evidenciase que o fisioterapeuta no NASF possui um papel importante junto as equipes de saúde no que se refere a atenção as demandas do município, no entanto, ficou evidente a necessidade de se consolidar o apoio matricial e o planejamento coletivo das ações.

Palavras-chave: Saúde da Família. Recursos Humanos em Saúde. Fisioterapia.

\section{Introduction}

The creation of Nucleus of Support for Family Health (NASF) jointly with the proposition of new juridical and legal, managerial and organizational, theoretical and technical and assistance arrangements, such as the Pact for Health and the National Primary Care Policy, appear as attempts to overcome challenges and gaps that still are present in the Unified Health System (SUS) as to the effectiveness of some of its principles, such as comprehensive health care, universal access and equal (1).

The NASF were created to strengthen primary health care and support to the actions of the Family Health Strategy (FHS) according to the demands identified by the teams (2). The working process of the family health team and the NASF provides for the coordination and integration among its members since professionals of the nucleus assume responsibility with the population and the family health team (3).

The NASF team may be composed of professionals from various categories, such as social workers, pharmacists, nutritionists, physical educators, psychologists, and physiotherapists, among others. The definition of the composition of the teams is the responsibility of the municipal administration and should be based on demands derived from epidemiological data, local needs and teams to be supported (2).

The guidelines that direct the work process of NASF involve the integration between the manager, NASF teams, and family health in the definition of actions from these actors. It is worth noting that one of the assumptions of NASF regards to the need for routine moments of meeting for agreement and negotiation of the work process through case discussion, objectives definition, priority criteria and evaluation, among others. Thus, professionals must assume their responsibility of co-management and managers have the role of coordinating these processes in the construction of interdisciplinarity (3).

One of the technological tools for the development and organization of work in NASF is the matrix support that represents the integration of a specialist to several teams in need of their specialized work. It also aims to promote care support and the production of a systematic exchange space of knowledge among the various specialties and professions (4).

Concerning the physiotherapist's role in NASF team, studies have shown that, jointly with other professionals, perform interventions in specific population groups, home visits, integrative practices and complementary education actions and health promotion for families of territories assisted by the nucleus $(5,6)$.

About the perception of the health staff of the family as the role of physiotherapy in primary care, studies show that for these professionals, the physiotherapist is needed on the team due to the great demand of rehabilitation, like stroke, fractures and work diseases $(7,8)$. 
Given the understanding that the NASF is an innovative proposal and that the performance of all its team members, including the physiotherapist, is configured from the integration between various actors (managers, family health team and NASF staff) and, that the teamwork and the shared management constitutes its foundations, it is necessary to know the different looks that team members and coordination have on the way the physiotherapist acts in the nucleus, because this information may contribute to process improvement of work, in accordance with the NASF creation goals. To contribute to this debate, this production aims to present the perceptions of staff, coordinators of Family Health Centers (CSF) of reference and NASF, about the physiotherapist's role in the nucleus of the municipality of West Santa Catarina.

\section{Methods}

This is a qualitative research, guided by the case study method. The study was conducted in a municipality reference in health services for the western region of the state of Santa Catarina, which has 41 teams of FHS and four NASF. Each nucleus has a Health Centre Family (CSF) of reference, i.e., a health unit where the professionals are registered within a service territory of family health teams.

Four coordinators responsible by CSF of reference composed the population for NASF and the general coordinator of the nucleus. Two psychologists, two pharmacists, two social workers, one physical educator and one nutritionist also participated in the study, totalizing eight representatives of NASF team.

For coordinators, the technique used for data collection was semi-structured interviews, guided by a list of questions about the perception of the coordinators about the role of the physiotherapist in NASF.

With the members of the NASF team, data were collected in a focus group, interview or conversation type in small and homogeneous groups (9) and followed the script with guiding questions about the perception of professionals about the role of the physiotherapist in NASF. The group was held in a classroom of a municipal educational institution.

In both techniques, the lines were recorded in digital recorder and to preserve the anonymity of the subject were established codes for each one, according to the group to which belonged, i.e., the coordinators were assigned $\mathrm{C} 1, \mathrm{C} 2, \mathrm{C} 3, \mathrm{C} 4$ and $\mathrm{C} 5$ and team members $\mathrm{E} 1$, E2, E3, E4, E5, E6, E7 and E8.

Data analysis was done through thematic content analysis, following the guidelines of Minayo (9), i.e., preanalysis, material exploration and treatment of results and interpretation. The subjects who agreed to participate in the study signed the Informed Consent and the research project that originated this study was approved by the Research Ethics Committee of Unochapecó under the Protocol n. 044/13.

\section{Results and discussion}

Concerning the perception of the staff, CSF reference coordinators, and NASF, about the work of physiotherapists in the nucleus and with the FHS team, after content analysis, some analytical categories emerged, as shown below.

Physiotherapist's role at NASF

\section{- Health Education and Disease Prevention actions}

For subjects heard in the study, the physiotherapist performing their work in NASF, develops health education activities in home visits, as evidenced in these reports:

"We observed that the caregiver, after visiting the physiotherapist, starts doing the exercises he taught. This is a positive result."(E2). "Home visits to bedridden patients is important because when they go to physiotherapy, they are already better, they can already make some movements because they did not stay at home without any guidance." (C4).

Torres et al. (10) affirm that home visit is a strategy that allows taking health education to users who have difficult access to health services. A Dibai Son and Aveiro (6) study, performed with physiotherapists from NASF of Arapiraca-AL, also found that home visits are a routine of these professionals and have the objective to enable caregivers and family members, to intervene in ergonomic aspects of house and furniture and make referrals to the services of reference. These visits favor the co-responsibility of care, do not generate the user dependence and enable the attendance of a greater number of people (11). 
To include assistance to the family members with rehabilitation needs is recommended by the guidelines of NASF and is important for humanized care, comprehensive and effective, and must understand the actions of psychosocial support, guidelines for carrying out the activities of daily living, specialized support offering in hospital or home confinement, among others (3).

Also cited the actions of health education and disease prevention performed in groups of specific populations as important activities performed by NASF physiotherapist, as evidenced in the reports below:

"The physiotherapist has an important role in groups because teaches what patients can do at home. Also in the walking group, do stretching and guides each case. When someone has difficulty, with tendinitis, for example, indicates which is the best exercise." (C1). "These days I went to a council meeting of health and women were saying that the physiotherapist had participated in a unit group. He made guidance on how to sweep the house, how to mop and they were talking about how much they had improved. Thus, the education and prevention actions in groups, talking about posture, basic activities, are important because they often decrease the patient's pain, only with guidance." (C2).

The process of education and postural orientation collectively built figures as a possibility of physiotherapist's role in primary care. Postural orientations may represent a preventive factor for several diseases and should take into account habits, customs, and beliefs with the power to influence the attitude of the community (12).

The literature review conducted by Portes et al. (13) about the role of physiotherapy in primary care, found that most of the articles on the subject, report health education activities, from guidance to patients and their families and the community guidelines about disease prevention.

Health education is an instrument for the promotion of quality of life of individuals, families and communities (14). Oliveira and Weendhausen (15) believe that health education can modify the assistance; it is an essential tool for building integrity and becomes an instrument of empowerment of individuals and communities when its approach is made of dialogue, emancipatory and participatory manner.

About the diseases prevention, the report of a team professional highlights that:
"Prevention activities performed in groups by physiotherapists are important, although they are often for people in pain. They act seeking the prevention of recurrence and improving the quality of life. It is well known that people who go to the groups say they feel better; they are taking less medication to sleep. We have no idea of numbers, but we see in the daily, testimonies of people who report improvements in health." (E5).

Interventions in the territory and health of population groups are cited as actions to be developed by NASF professionals (2). The use of educational, support and treatment groups is expected in nine strategic areas of NASF, namely: health of the child/adolescent and young; mental health; rehabilitation/integral health of the elderly; feeding and nutrition; social service; women's health; pharmaceutical care; physical activity/body practices; complementary and integrative practices (3).

About incentive groups, physical activity and body practices, the programming of these actions should be agreed between NASF and ESF professionals, from the knowledge of mortality indicators and specificities of each territory (3). In this sense, the physiotherapist can contribute to the monitoring of functional kinetic disorders, it's monitoring, and follow-up and should take responsibility for kinesiology and functional health of the population in the territories where works (12).

- Flow organization and management of users with rehabilitation demand

It is shown in the reports of coordinators that there is an unmet demand for rehabilitation in the city, existing before NASF implantation, and the role of the physiotherapist in the nucleus aims also to organize and manage the users flow with this need, either by forwarding to covenant clinics, or to follow the NASF groups, as the following lines:

"We have a repressed demand for physiotherapy rehabilitation at the NASF. The NASF physiotherapists now evaluate referrals and make a 'screening' of these patients, an evaluation of those who need care in clinics of reference and who can be referred to the Pilates group. Then, the scheduling and organization of the repressed demand have been resolute in the physiotherapist's work." (C5).

Another coordinator also evaluates as positive the role of the physiotherapist about the organization of 
the flow of users and referral to reference clinics and specific groups:

"If the physiotherapist evaluates that the patient does not need to go to the clinic, but needs a physical activity, she conduct them to the group. She can do this management, who need treatment in clinics or who can participate in specific population groups. She also makes the monitoring of patients who must continue treatment in clinics, making an initial assessment and, if necessary; she conduct them again. Thus, we are reducing the waiting lists for physiotherapy." (C1).

It is noted in these statements that the physiotherapist's performance translates into a better organization of the flow of users in need of rehabilitation, and the reduction of waiting lists for treatment in clinics of reference. From these reports, it is the reflection of Silva et al. (16) that the expectation of managers with NASF is the better resolution of basic care, whether through interdisciplinary actions and improving access to services, or through the demand reorganization and reduction of demand for services related to secondary and tertiary care as a gateway to the system.

Individual assessments and referrals are related to actions developed by physiotherapists in studies that address the role of this professional at $\operatorname{NASF}(17,18)$. These procedures show one of NASF assumptions, where the team takes the user responsibility even when they have a need that primary care does not address, such as a prolonged treatment. It is still an attribution of NASF professionals, to receive users who require rehabilitative care, conducting to their monitoring and referral to specific services performed to another level of care (3).

Thus, the role of the physiotherapist in the studied city also assumes the function of the organization's demand for care in the field of Physiotherapy, and the establishment of strategies to meet this need.

\section{- Prevention and treatment of occupational diseases}

Due also to the high demand for physiotherapy, mainly related to the profile of municipal workers, team members, and coordinators believe that the insertion of the physiotherapist in NASF occurred by this fact, and that guides its performance in tertiary care, as evidenced by these reports:
"I see that physiotherapists make a study of how the territory is, for example, here there are enough workers, so we have to focus more in this direction, there are many people with injuries." $(\mathrm{C} 2)$.

The reports express the physiotherapist's performance to users with illnesses related to work, especially cases of chronic pain:

"What I see, talking to physiotherapists, most of the cases that come to them is not, for example, rehabilitation of some surgery, fracture or something you will work a while and then the person will be released or will be discharged. Most cases are chronic pain, RSI [repetitive strain injury] requiring continuous treatment." (E8).

For one of the coordinators this reality is explained by workers' profile and the functions they perform:

"We have many [users] working in agribusiness and plenty cases of RSI and WMSDs [work-related musculoskeletal disorders]. There are many tendonitis injuries, joints, and spine. Those who do not work in agriculture or garden work in agribusiness or heavy lifting then leads to these diseases." (C4).

This situation resembles the assertion Fréz and Noble (19) to cite the increased demand for physiotherapy services is the functional recovery. This is due, in part, by the change in the epidemiological profile of the population, who currently lives with chronic diseases (12) and also by the growing number of elderly, by factors associated with aging that have greater vulnerability to diseases and disabilities (17).

Studies about the perception of FHS professionals, about the physiotherapist's role in primary care, show that this professional is still seen and valued in the team due to the rehabilitation needs. This recognition of professional depending on performance in the tertiary care is due to the history of the profession $(8,7,20)$.

In addition to the reception and supervision of workers who already have diseases, the NASF guidelines express the need to create partnerships with the Workers' Health Reference Centers in the development of safety and health actions in the workplaces, prevention of accidents and professionals diseases and coordination with other sectors such as education, social assistance, among others (3). 
Santos and Lacaz (21) describes the actions of matrix support in occupational health, held in a municipality of São Paulo, among them emphasizes thematic meetings, demands support and the production of information, reorganization of health work, the co-responsibility of the cases, the integration of surveillance and assistance actions and the creation of links between the professional health worker and family health.

Despite the demand for physiotherapy represent a daily life reality of NASF in the city, and the close relationship between the physiotherapist and practices at this level, their performance in primary care, according to Bishop Jr (12), should also include actions of health promotion and prevention diseases, in the search for the transformation of social and epidemiological reality, in view of the social inequalities in health and social exclusion.

\section{- Development of Integrative and Complementary Practices}

Another observed analytical category was the realization of integrative and complementary practices by physiotherapists in NASF territories, as auriculotherapy, which, in the opinion of actors, facilitates user access to these techniques.

"The work in groups inserting the integrative practices performed by physiotherapists are strategies that people would not have access without their presence in the team." (E7). "The auriculotherapy, which physiotherapists work, has been well accepted by the teams and the population, which has sought these practices increasingly." (E4).

The complementary and integrative practices are listed among the strategic areas of NASF and professionals should encourage the implementation of these practices in the FHS (3). Mendonça (22) adds that NASF enables the expansion of the supply of complementary and integrative practices for most chronic diseases and review of treatments based on medicalization. For Galhardi et al. (23) the inclusion of professionals working with complementary and integrative practices through NASF strengthens the integrity of health care in the FHS.

About auriculotherapy, Camargo, and Santos (24) reported the experience in the use of this acupuncture method and found that this decreased anxiety, sadness and insomnia to participant's users of a tobacco program in primary care.

It was also mentioned that the group uses the Lian Gong in 18 therapies, led by NASF physiotherapist:

"Last year I participated with the physiotherapist in Lian Gong group, and users for sure have improved with their pain, they say they like. And the good of these Lian Gong groups is that you learn the exercises and can do the movements at home too."

Lian Gong is a body practice provided in NASF Guidelines and consists of three series of exercises aimed at the prevention and treatment of spinal pain, shoulders and lower limbs (3). Silva et al. (25) presented the report of experience with this practice in a group of users with complaints of musculoskeletal pain, led by NASF physiotherapist of a municipality of the Federal District, where observed after the activity, improved integration and socialization of users, relief of pain and physical, mental and emotional well-being.

During the analysis content the subjects, besides highlighting the way the therapist works on NASF, pointed out some obstacles to the work process that need to be overcome to achieve the objectives.

Barriers to the physiotherapist's work process at NASF:

- Disjointed planning

In the view of one of the coordinators, the physiotherapist has difficulty in participating in the planning together with the ESF because of the partial workload and the accumulation of health units to support, as seen in this report:

"Till today, the physiotherapist did not participate in any of our meetings because, in addition to acting in many healthcare units, there are periods when she does not work in NASF. I've already requested her participation, but she can't at this time. One of the difficulties we have with the physiotherapist is they have many units to meet and little time to participate in our activities."(C1).

The NASF professional of Fortaleza (CE), heard by Oliveira et al. (18) also considered that the accumulation of health units to support prevents the creation of linkages and knowledge of the territory. Despite these 
findings, the law of NASF regulates each nucleus type 1 , in cities with over than one hundred thousand inhabitants, such as the municipality under study, may be linked to at least eight and no more than 15 family health teams and/or primary care teams for specific populations (2).

This regulation, however, does not favor the participation of the physiotherapist in the ESF planning meetings, since it was observed that their workload and work schedule, in the case of the studied city, does not match the family health team. Another limiting factor is the partial workload performed by the physiotherapist (twenty hours per week) while the FHS professionals mostly work forty hours; therefore, the discussion of cases, appointments, and shared care are also affected.

In the reality studied by Moura and Luzio (1), after performing a participant observation of the actions developed by the professionals of the seven NASF of Maringa (PR), linked to an average of nine ESF, reported the participation of physiotherapists in the weekly family health meetings, where the matrix support was concretized through the discussion of cases of users and families, conducting singular therapeutic projects, health projects in the territory and the participation elaborating Health Annual Plans of Municipal Secretary. However, it is noteworthy that in the reality studied by these authors, the municipality has seven NASF, and only one was observed, due to it was the more consolidated and articulated to the network, and therefore being another nucleus with difficulties.

In this study, it was observed that the non-involvement of the physiotherapist in planning implies the disconnection between the ESF and NASF teams, as expressed in this speech:

"I think the physiotherapists don't act in the planning because they have nine units to act. Our physiotherapist is in NASF only twenty hours; she is here half a day a week, on Wednesday morning. I think the NASF is isolated from the ESF. It's been three and a halfyears that I'm here; I can visualize well because I followed it from the beginning. They make their actions, but isolated. of course, if I have a problem with a patient and talk or ask a guideline, it happens, but they are isolated." (C3).

This finding is worrisome because it is necessary NASF being integrated into family health teams, with an interaction between the knowledge nucleus, dynamically, to ensure the construction of attention without fragmentation (16). Molini-Avejonas (26) bring to the discussion the importance of vocational training, since they consider as a challenge for professionals in the NASF the creation of joint performances, integrated and intersectoral, as these practices are not performed during graduation, making professionals learning to work collectively, in the daily actions and in the immersion in the territory, the place where life happens.

The team professionals, based on their experience, they also recognize that planning still needs to be qualified, as these testimonials:

"I went into the NASF one year and a half ago, but I didn't participate effectively in any planning. I participated at the end of the year, in a moment when we organize to decide who would take the groups, who would support those in the units. I understand that planning is a broader process in which epidemiological data are used, and the highest incidence in the territory are priorities in the organization of actions and that after the interventions we need to evaluate the impacts of what we do. In this sense, we do not do it. We don't do as NASF. We don't produce information with the data we have, and we don't make planning and evaluation, as it should."(E5). "Most of the health units do not have a moment of planning. At least in our, most are like that. It is not done a study using data from the SIAB [Information System of Primary Care], of epidemiological surveillance." (E8).

Reality different from this is shown in the study of Gonçalves et al. (27) where, in the implementation process of NASF of São Paulo, most of the workload of the professionals was intended for planning actions. One of NASF objectives refers to the creation of spaces where NASF and ESF professionals meet up for a collective learning process (3). The planning of actions in an interdisciplinary way should be guided by the needs of the population groups to be served, limited not only to the role of each professional (28). These meetings should focus on defining objectives, priority criteria and work assessment, conflict resolution, discussion of cases and situations (3).

It is also worth reflecting here on the importance of family health teams and NASF knowing the reality of the territory to identify, together with the community, the priority public for action, encourage the evaluation together with the Municipal Health Councils for monitoring the development and implementation of actions and their impact on health situations; also make the pact of the work process and targets among 
professionals from the NASF, the ESF and managers (3). Before the reports, it may be noted that the principles of NASF described above, are still not organized in the city. The coordinator of the nucleus recognizes this reality, and highlights change initiatives this scenario:

"Today, we are in a very hard work to reshape the NASF, in the direction of specialist orientation, support teams first, then the groups and finally the individual care. Today, we are working on it, and we have some change movements." (C2).

The matrix support is an important element in the work of NASF professionals; the involved actors need to promote collective spaces for reflection, discussion, and practice to enhance the communication between teams, creating trust ties and respect for building partnerships needed to work team (29). It reflects here the importance of managing to encourage these changes, to mediate and negotiate the articulation between the teams of family health and NASF, and re-evaluate and reprogram the actions from the impact indicators about population's health.

-Prioritization of action in rehabilitation

Another obstacle that emerged after the analysis was the professional performance that gives priority to rehabilitation, rather than disease prevention actions. For the interviewee subjects, NASF physiotherapists should work more with preventive activities as evidenced in this speech:

"In fact, if you look at the logic of NASF, they [physiotherapists] may be working a little unfocused than it should be done. At least, this is my point of view. It is known that the main function of any NASF agent, regardless of the category, is primarily working the matrix support, i.e., give pedagogical-technical support to the team and then work on the promotion and prevention. The physiotherapist of our NASF is working with rehabilitation when you already have an installed problem." (E4).

Other professional beliefs that illness prevention actions could provide better resolution to the actions of NASF:

"It would have more resoluteness if the physiotherapists would perform a preventive work. I think that would decrease the number of injury cases." (E7).
A study of the role of the physiotherapist in NASF showed that in the view of FHS professionals, this professional contributes to the health actions being resolving, acting in health promotion and injury prevention and the development of coordinated activities with the team (30).

In the view of one of the coordinators, the physiotherapist support to ESF is aimed at the rehabilitation of diseases due to the demand:

"The physiotherapist is supporting the ESF more in rehabilitation. We should direct more, at least, one part of prevention. I think the demand is very large, and they are failing to do prevention, they are only doing rehabilitation." (C4).

Another considers it should be important to develop disease prevention measures for members of the FHS teams:

\begin{abstract}
"We will think about next year to resume some actions that we already had, such as physical activity for the team. The physiotherapist should do some work for us because we are here with bad posture. This issue with professionals is still a little shy; it should be more explored regarding health promotion and prevention for us." (C5).
\end{abstract}

This situation can be explained because before the implementation of NASF in the municipality, there was not physiotherapist inserted in primary care and next to this is added the health reality of the city, that has many workers with musculoskeletal injuries, and therefore, high demand for physiotherapy service. Allied with the consolidation of the area in tertiary care, physiotherapists, when inserted into the NASF, began organizing their operations to meet this need and organize the flow of these users. However, it is noteworthy that, although the NASF physiotherapist has responsibilities in this regard, others have not been implemented in the municipality, as the matrix support. Also, the actions of disease prevention and health promotion are also part of the scope of action of NASF professionals.

\section{Conclusion}

In seeking to understand the perception of the coordinators and team members about the physiotherapist's role in the nucleus, it was observed that in their view, these professionals contribute to improving the health of families living in the territories in which they operate, 
with health education actions and prevention of disease, both in the collective framework, jointly with specific groups of the population, as in the home visits, in the organization and management of users who require rehabilitation, in the attention to workers' health and the use of complementary and integrative practices. It argues that the role of the physiotherapist in the studied context is organized, from the population's needs, which is in agreement with the recommendations in the NASF guidelines.

Concerning the obstacles, one of the observed features is the high demand for rehabilitation in the city, and the NASF by its multidisciplinary composition must balance the health promotion, disease prevention, and rehabilitation. Physiotherapy, in this context, is faced with a challenge, which is to act in the organization of this flow, but focus on creating strategies to promote the health of families, as recommended by the FHS.

Both coordinators as the team members recognize that planning between ESF and NASF remains a challenge in the nucleus consolidation. The difficulty of the physiotherapist participation, according to the actors, is due to their different working schedule and the accumulation of health units to support. However, reports of other NASF professionals, who perform forty hours a week, likewise, showed the difficulty in articulating the actions together with ESF. It was also raised the need for actions planning using epidemiological data of the territory.

Given these results, we observe that the physiotherapist work in NASF, still faces challenges to effect interdisciplinarity, co-responsibility, and comprehensive care. Here lies the importance of management to ensure permanent education actions for health professionals working in both the NASF, as the ESF, to qualify the work process to improve the outcomes of primary care.

In this sense, there is a need for further research on this issue, describing the different experiences of the teams, professionals and managers of NASF, in different Brazilian realities, so we can qualify and consolidate the nucleus as ESF supporting, from the publicity of the results.

\section{References}

1. Moura RH, Luzio CA. O apoio institucional como uma das faces da função apoio no Núcleo de Apoio à Saúde da Família (NASF). Interface (Botucatu). 2014;18(1):973-86.
2. Brasil. Portaria n⿳0 2.488, de 21 de outubro de 2011. Aprova a Política Nacional de Atenção Básica, estabelecendo a revisão de diretrizes e normas para a organização da Atenção Básica, para a Estratégia Saúde da Família (ESF) e o Programa de Agentes Comunitários de Saúde (PACS). Brasília: Ministério da Saúde. [cited 2014 Jun 4]. Available from: http://tinyurl.com/h2ma9v8. Portuguese.

3. Brasil. Cadernos de Atenção Básica: diretrizes do NASF. Brasília: Ministério da Saúde; 2009. Portuguese.

4. Campos GWS, Domitti AC. Apoio matricial e equipe de referência: uma metodologia para gestão do trabalho interdisciplinar em saúde. Cad Saude Publica. 2007;23(2):399-407.

5. Barbosa EG, Ferreira DLS, Furbino SAR, Ribeiro EEN. Experiência da Fisioterapia no Núcleo de Apoio à Saúde da Família em Governador Valadares, MG. Fisioter Mov. 2010;23(2):323-30.

6. Dibai Filho AV, Aveiro MC. Atuação dos fisioterapeutas dos núcleos de apoio à saúde da família entre idosos do município de Arapiraca-AL, Brasil. RBPS. 2012;25(4):397-404.

7. Souza MC, Araujo TM, Reis Jr WM, Souza JN, Vilela ABA, Franco TB. Integralidade na atenção à saúde: um olhar da equipe de saúde da Família sobre a fisioterapia. Mundo Saude. 2012;36(3):452-60.

8. Oliveira G, Andrade ES, Santos ML, Matos GSR. Conhecimento da equipe de saúde da família acerca da atuação do fisioterapeuta na atenção básica. RBPS. 2011;24(4):332-9.

9. Minayo MCS. O desafio do conhecimento: pesquisa qualitativa em saúde. 12th ed. São Paulo: Hucitec; 2010. Portuguese.

10. Torres HC, Santos LM, Cordeiro PMCS. Visita domiciliária: estratégia educativa em saúde para o autocuidado em diabetes. Acta Paul Enferm. 2014;27(1):23-18.

11. Formiga NFB, Ribeiro KSQS. Inserção do Fisioterapeuta na Atenção Básica: uma Analogia entre Experiências Acadêmicas e a Proposta dos Núcleos de Apoio à Saúde da Família (NASF). RBCS. 2012;15(2):113-22.

12. Bispo Jr JP. Fisioterapia e saúde coletiva: desafios e novas responsabilidades profissionais. Cien Saude Colet. 2010;15(1):1627-36. 
13. Portes LH, Caldas MAJ, Paula LT, Freitas MS. Atuação do fisioterapeuta na atenção básica à saúde: uma revisão da literatura brasileira. Rev APS. 2011;14(1):111-9.

14. Sousa LB, Torres CA, Pinheiro PNC, Pinheiro AKB. Práticas de educação em saúde no Brasil: a atuação da enfermagem. Rev Enferm UERJ. 2010;18(1):55-60.

15. Oliveira SRG, Wendhausen ALP. (Re)significando a educação em saúde: dificuldades e possibilidades da Estratégia Saúde da Família. Trab Educ Saude. 2014;12(1):129-47.

16. Silva ATC, Aguiar ME, Winck K, Rodrigues KGW, Sato ME, Grisi SJFE, et al. Núcleos de Apoio à Saúde da Família: desafios e potencialidades na visão dos profissionais da Atenção Primária do Município de São Paulo, Brasil. Cad Saude Publica. 2012;28(11):2076-84.

17. Linhares JH, Pinto PD, Albuquerque IMN, Freitas CASL. Análise das ações da fisioterapia do NASF através do SINAI no município de Sobral-CE. Cadernos ESP. 2010;4(2):32-41.

18. Oliveira PRS, Reis F, Arruda CAM, Vieira ACVC, Tófoli LF. Novos olhares, novos desafios: vivências dos Núcleos de Apoio à Saúde da Família em Fortaleza - CE. Cadernos ESP. 2012;6(1):54-64.

19. Fréz AR, Nobre MIRS. Satisfação dos usuários dos serviços ambulatoriais de fisioterapia da rede pública. Fisioter Mov. 2011;24(3):419-28.

20. Cogo LA, Freitas CS, Ribeiro JS, Vogt MSL, Miolo SB. Percepção dos agentes comunitários de saúde sobre a fisioterapia na atenção primária. Saude (Santa Maria). 2013;39(1):101-11.

21. Santos APL, Lacaz FAC. Apoio Matricial em Saúde do trabalhador: tecendo redes na Atenção Básica do SUS, o caso de Amparo/ SP. Cienc Saude Colet. 2012;17(5):1143-50.

22. Mendonça CS. Saúde da família, agora mais do que nunca. Cienc Saude Colet. 2009;14(1):1493-7.

23. Galhardi WMP, Barros NF, Leite-Mor ACMB. O conhecimento dos gestores municipais de saúde sobre a Política Nacional de Prática Integrativa e Complementar e sua influência para a oferta de homeopatia nos Sistema Único de Saúde local. Cienc Saude Colet. 2013;18(1):213-20.

24. Camargo TCA, Santos CA. Evidências da auriculoterapia no programa de tabagismo na Atenção Básica. In: Anais do $12^{\circ}$ Congresso Brasileiro de Medicina da Família e Comunidade; 2013 May 29 - Jun 2; Belém, Brazil. Portuguese.
25. Silva LB, Costa CT, Nery MCP. Lian gong em 18 terapias: uma experiência de humanização e integralidade. In: Anais do $12^{\circ}$ Congresso Brasileiro de Medicina da Família e Comunidade; 2013 May 29 - Jun 2; Belém, Brazil. Portuguese.

26. Molini Avejonas DR, Mendes VLF, Amato CAH. Fonoaudiologia e Núcleos de Apoio à Saúde da Família: conceitos e referências. Rev Soc Bras Fonoaudiol. 2010;15(3):465-74.

27. Gonçalves RMA, Lancman S, Sznelwar LI, Cordone NG, Barros JO. Estudo do trabalho em Núcleos de Apoio à Saúde da Família (NASF), São Paulo, Brasil. Rev Bras Saude Ocup. 2015;40(131):59-74.

28. Andrade LMB, Quandt FL, Campos DA, Delziovo CR, Coelho EBS, Moretti-Pires RO. Análise da implantação dos Núcleos de Apoio à Saúde da Família no interior de Santa Catarina. Sau \& Transf Soc. 2012;3(1):18-31.

29. Barros JO, Gonçalves RMA, Kaltner RP, Lacman S. Estratégia do apoio matricial: a experiência de duas equipes do Núcleo de Apoio à Saúde da Família (NASF) da cidade de São Paulo, Brasil. Cienc Saude Colet. 2015;20(9):2847-56.

30. Souza MC, Bomfim AS, Souza JN, Vilela ABA, Franco TB. Fisioterapia e Núcleo de Apoio à Saúde da Família: um estudo sob a ótica dos gestores, profissionais e usuários de saúde da família. Rev APS. 2014;17(2):189-94.

Received in 12/16/2014 Recebido em 16/12/2014

Approved in 12/103/2015 Aprovado em 03/12/2015 